\title{
Effect of a very Small amount of Thyroxine on Survival of Chicks Exposed to Cold
}

\author{
Kihachiro NobUkUNI and Hisayoshi NishiYama \\ Faculty of Agriculture (46-06), \\ Kyushu University Fukuoka-shi 812
}

(Received March 8, 1979)

NoBUKunI and KOGA" reported that most of thyroidectomized chicks died within one day after the onset of cold exposure, while only a small number of the chicks to which thiouracil had been administered died from cold exposure. From these results they assumed that feeding of thiouracil might not cause a complete deficiency of thyroid hormone unlike that occurring following thyroidectomy, and that a very small amount of the hormone secreted could make chicks survive in cold temperatures.

In the present experiment, this assumption was further investigated and the effects of a small amount of thyroxine on the survival of chicks in cold were studied.

\section{Materials and Methods}

Commercial male chicks (Shaver Strain) were used in this experiment. They were kept in a brooder $\left(30-32^{\circ} \mathrm{C}\right)$ from 1 to 7 days of age and thereafter reared in an air conditioned room at temperatures ranging between 20 to $24^{\circ} \mathrm{C}$ until the beginning of cold exposure. The chicks were divided into 5 groups. The chicks of Group 1 were surgically thyroidectomized at 11 or 12 days of age by a slight modification of the method described by Marvin and SMITH'). The chicks of Groups 2 and 3 were thyroidectomized as in the case of Group 1, and daily dose of $90 \mathrm{ng}$ (Group 2) and $60 \mathrm{ng}$ (Group 3) of L-thyroxine per $100 \mathrm{~g}$ body weight was injected into pectoral muscles from 2 weeks before the onset of cold exposure (13 days of age) to the end of the treatment. L-thyroxine (Nutritional Biochemical Co.) was dissolved in a 1:1 mixture of propyleneglycol and $0.1 \mathrm{~N} \mathrm{NaOH}$ and was diluted with distilled water to give the desired final concentration of thyroxine. The injection dose was determined by the results of preliminary experiments. The chicks of Groups 4 and 5 were fed a ration containing $0.1 \%$ thiouracil (Nutritional Biochemical $\mathrm{Co}$.) ad libitum, from 1 week (Group 4, 20 days old) and 2 weeks (Group 5, 13 days old) before cold exposure, respectively to the end of the treatment.

低温環境下での䳕雛の生存に対する微量サイロキシンの効果：信国喜八郎・西山久吉（九州大学農学 部, 福岡市 812)

Jap. J. Zootech. Sci., $50(9): 676-678$ 
The chicks of all groups were exposed to $5^{\circ} \mathrm{C}$ for 6 days from 28 days of age, and the number of chicks which survived and survival time were recorded during the treatment. Survival time was defined as the number of days from the beginning of cold exposure to the death of the chicks.

All chicks, including dead ones, were autopsied to confirm the complete absence of thyroid gland through thyroidectomy. Thyroid region was examined macro- and microscopically, and if thyroid tissue was found, the chicks were omitted from the data.

\section{Results and Discussion}

The results are shown in Table 1. All thyroidectomized chicks (Group 1) died within 2 days after cold exposure. In contrast, most of the thyroidectomized chicks injected $90 \mathrm{ng}$ of thyroxine (Group 2), which was equivalent to only one twentieth the amount of the hormone estimated to be secreted per day in normal chicks $(1.7 \mu \mathrm{g} / 100 \mathrm{~g}$ bwt $\left.\cdot \mathrm{day}^{3}\right)$, survived throughout the experimental period. Even when one thirtieth of the amount of hormone secreted was injected (Group 3), half of the chicks tested survived. These results indicate that a very small amount of thyroxine is sufficient to make the chicks survive in cold environments.

On the other hand, in the chicks to which thiouracil had been administered from 1 week (Group 4) and 2 weeks (Group 5) before cold exposure to the end of the treatment, all and 6 out of 10 chicks survived throughout the experimental period, respectively. The resuults are similar to those obtained by NoBUKunI and Koga ${ }^{11}$, and the difference in the number of chicks which survived between the two groups may be due to the duration of thiouracil administration. The degree of hypothyroidism is

Table 1. Number of chicks died and survival time in thyroidectomized chicks injected a small amount of thyroxine and in chicks administered thiouracil.

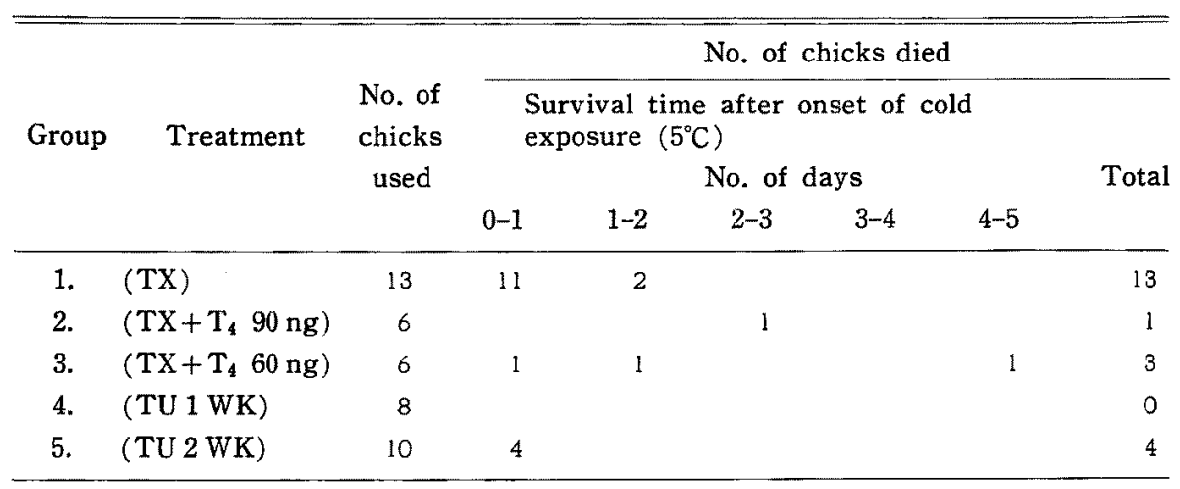

Footnote. TX: Thyroidectomy 2 weeks before cold exposure $\left(5^{\circ} \mathrm{C}\right) . T X+T_{i} 90 \mathrm{ng}$ : Thyroidectomy and injection of $90 \mathrm{ng}$ L-thyroxine per $100 \mathrm{~g}$ bwt. per day from 2 weeks before cold exposure $\left(5^{\circ} \mathrm{C}\right)$ to the end of the treatment. $\mathrm{TX}+\mathrm{T}_{4} 60 \mathrm{ng}$ : Thyroidectomy and injection of $60 \mathrm{ng} \mathrm{L}$-thyroxne per $100 \mathrm{~g}$ bwt. per day from 2 weeks before cold exposure $\left(5^{\circ} \mathrm{C}\right)$ to the end of the treatment. TU $1 \mathrm{WK}$ : Thiouracil administration $(0.1 \%$ in ration) from 1 week before cold exposure $\left(5^{\circ} \mathrm{C}\right)$ to the end of the treatment. TU $2 \mathrm{WK}$ : Thiouracil administration $\left(0.1 \%\right.$ in ration) from 2 weeks before cold exposure $\left(5^{\circ} \mathrm{C}\right)$ to the end of the treatment. 
considered to increase with lengthening the administration period. Wentworth and MELLEN ${ }^{4}$ reported that thyroid hormone synthesis was not completely inhibited by thiouracil adnimistration. Therefore, the present results confirm the previous suggestion made by NOBUKuNI and KoGA ${ }^{1 /}$ that a very small amount of thyroid hormone may be secreted in the chicks which had received thiouracil and that the hormone may be effective for survival in cold.

In summary, it is concluded that thyroid hormone is essential for survival of chicks in cold and exerts a favourable effect even in very small amounts. Thiouracil administration causes severe inhibition of secretion of thyroid hormone and only a very small amount of the hormone continues to be secreted.

\section{References}

1) Nobukuni, K. and O. KogA, Jap. J. Zootech. Sci., 46: 154-160. 1975.

2) Marvin, H. N. and G.C. Smith, Endocrinol., 32: 87-91. 1943.

3) Nobukuni, K. and S. Окамото, Jap. Poult. Sci., 9: 11-16. 1972.

4) Wentworth, B.C. and W. J. Mellen, Poult. Sci., 40: 1022-1025. 1961. 